\title{
The ANalysis of NeEdS On Learning Materials in CONTEXT- BASED READING MANDARIN LANGUAGES AND CULTURE
}

\author{
Febi Nur Biduri ${ }^{1)}$, Yumna Rasyid ${ }^{2)}$, Emzir $^{3)}$ \\ 1) Darma Persada University, Jakarta, Indonesia \\ E-mail:febinur@gmail.com \\ ${ }^{2)}$ State University of Jakarta, Indonesia \\ E-mail: yumna.rasyid@unj.ac.id \\ ${ }^{3)}$ State University of Jakarta, Indonesia \\ E-mail: emzir.unj@gmail.com
}

\begin{abstract}
A research and development of teaching materials will focus on the development of the textbook that suit the needs of students, lecturers, and also the majors. The knowledge of culture and literature that has been studied in Chinese Language and Culture study program of Darma Persada University is not maximum and suitable for the students' needs. So to adjust to the needs of these students, the making of teaching materials in this study will use the contextual based theme of Chinese literature and culture. The literature and cultural themes used in this study consists different types of traditional Chinese folklore. The methodology used in this study refers to Hutchinson and Waters theory that includes the analysis of the needs of students and teachers. The data collections are conducted using questionnaire in the $5^{\text {th }}$ of Chinese Language and Culture Faculty of Darma Persada University which consist of 18 students and 3 lecturers in reading class. The data analysis used in this study is quantitative. This research resulted that the use of appropriate teaching materials and in accordance with the needs of students will result in more effective learning, better learning outcomes, and a positive response on student attitudes. The material for reading the context-based Mandarin literary works and culture resulting from this development research has also encouraged the students to be more active during the teaching and learning process.
\end{abstract}

Keywords: Students' and teachers' needs; teaching material results; reading by theme; contextual teaching; learning to read Mandarin

\section{INTRODUCTION}

A research and development of teaching materials will focus on the development of textbook products that suit the needs of students, lecturers and also majors. The knowledge of culture and literature that has been studied in Mandarin studies program, Darma Persada University, is not maximal and in accordance with the needs of students. So, to adjust to the students' needs, creating teaching materials in this study was using the contextual Chinese literature and culture theme. The teaching material reads $\mathrm{V}$ which is made using Chinese-themed literary and cultural texts. The literary and cultural texts referred by researchers are the literary texts of folklore.
The curriculum used in making this teaching material is International Curriculum for Chinese Language Education (ICCLE). In this curriculum, there are 5 levels, and the teaching materials that will be made are intended for level 5 of this curriculum. This curriculum is a reference for schools or universities conducting Chinese lessons worldwide.

In accordance with International Curriculum for Chinese Language Education level 5, the purposes of learning to read Mandarin for foreign speakers are as follows:

1. Understand the text and can describe the content of the text material, determine the important part of the text, and understand the structure of the text. 
2. Understand the composition of narrative texts that have several words, idioms, and figurative languages.

3. Understand the description and recognition of some new words and can specify some of the information contained in the text.

4. Understand some of the slang associated with work, school or daily life.

It was also mentioned by Jewitt that As digital technologies are becoming increasingly common in classrooms it is possible, and relatively easy, for students to create multimodal texts as a classroom activity in language education. When engaging in the activity of creating texts in language education, the students are expected to create an object, a text. The text can be considered a literacy object as it displays the students' ability to express meaning.

Thus the teaching of Mandarin as a foreign language skill aims to enable students to understand complex language material, to define ideas in text, to identify details and structure in the text.

The syllabus used in the International Curriculum for Chinese Language Education consists of an integrated syllabus. An integrated syllabus is a syllabus combining various syllabus types into one.

After the process of needs analysis toward the teaching materials, then start to compile the amount of teaching materials that will be used in a learning period, both in terms of type and quantity. There are two qualities in preparing teaching materials that are related to other teaching materials, so that they should pay attention to each other and the stand-alone teaching materials. Teaching materials created in this study are the teaching materials that relate between Mandarin literature and culture with contextual approach.

The teaching materials focus on the students and emphasize the development of special reading skills using literary and cultural themes. The basic idea of the concept of making the teaching materials is "the students can learn from personal experience", so that the students do not just learn to get grades only. The emphasis of these teaching materials is how to improve students' reading ability in subconscious thinking to develop reading comprehension skills.

The approach used in this textbook is a contextual approach. The contextual approach is a conception that helps the lecturers to relate the subject contents into real situations in the community and motivate the students to make connections between knowledge and application in their lives. Contextual learning states that the achievement of the graduates' learning is through a process of learning tailored to the demands of ability to solve problems in the realm of expertise.

Contextual learning is a learning that occurs in close connection with the real experience. Contextual teaching has 7 components: constructivism, inquiry, learning community, modelling, reflection, and authentic assessment. Classroom learning can be said that use a contextual approach if one or all of the above components really arise in the implementation of learning.

The contextual approach has seven main components: constructivism, inquiry, questioning, learning, modelling, reflection and authentic assessment. A class is said to use this approach when applying the seven principles into the learning process. The contextual approach can be applied in any curriculum, any field of study and any class of circumstances.

So, broadly, the steps of applying contextual approach in reading material are as follows:

1. Developing the students' thinking to learn more meaningfully by working alone, finding and constructing their own new knowledge and skills.

2. Implementing inquiry activities for all reading themes.

3. Developing the students' curiosity by asking questions.

4. Creating learning societies (learning in groups).

5. Presenting models as examples of learning.

6. Reflecting at the end of the meeting.

7. Conducting a true assessment in various ways.

Thematic teaching is a language teaching activity that focuses on the content of the text and emphasizes the diversity of concepts. This book uses Chinese literary and cultural themes to guide each theme which each subdivided into a small theme. This theme is interconnected with each other, forming a network of knowledge that will trace the memory of students.

\section{LITERATURE REVIEW}

Needs analysis is a learning base centered on the learner. This activity must be done carefully so that no party feels aggrieved because everything he planned is not as expected. Needs analysis will make it easier for developers to prepare their teaching materials. By providing the desired learner based on the results of needs analysis, the developer only designs as requested, according to the objectives to be achieved by learner and learner. 
In learning a foreign language, knowing everything that a learner needs will help the program organizers run the program according to plan. General and specific needs of learners who have poured in the lesson plans can make the program run smoothly, so that the targeted goals will be achieved. The thing that often happens is the learner feels not getting something he needs so reluctant to do the things suggested by the teacher. On the other hand, the teachers find it difficult to run programs to match the expected achievements because the learners are not motivated to do what the program has planned. Two-way cooperation will greatly assist the implementation of the program according to the achievements that are determined based on the needs of learners.

Munby in Communicative Syllabus Design said that designing a program model that suits the needs of the learners is important in learning a foreign language. Needs analysis is the first step for the preparation of syllabi, courses, teaching materials, or various things related to this. The needs analysis process always starts from the needs and background of the learner. With various instruments recorded their communication needs to be processed into a profile needs. Of course, each individual has a unique need, but with this analysis the teacher and program organizers can find the average ability and needs of a group of learners.

Jordan defines needs analysis as a process of determining the needs of a group of language learners and prioritizing learning materials based on those needs from both subjective and objective information.

Jordan provides guidance that program organizers can undertake to analyze learner needs.

a. Determine the purposes of the analysis; the program organizer must be able to determine the purposes of the analysis so that this activity is not in vain because it certainly takes time, personnel, and special skills in making analytical instruments. These goals will help the program organizers pursue the syllabus to be used, the teaching materials to be delivered, the design to be applied, for general or specific learning purposes, and so on.

b. Limit the number of learners to be analyzed; this will help program organizers in determining the learners' specific needs and separating less important needs.

c. Decide which approach to use; program organizers can discuss with the team in the field in determining the approach to be undertaken in conducting this needs analysis. d. Pay close attention to the obstacles to be faced; the program organizer must recognize the limitations that it may have in order to find a solution in its follow-up.

e. Choose data collection methods; in analyzing the learners' needs, the organizers can determine what method to use, spread questionnaires, written examinations, presentations, interviews or others.

f. Collect data; after careful preparation, it can continue in the process of collecting data from the respondents being analyzed.

g. Analyze and interpret results; once the data has been collected, the organizer through the implementing team can analyze the available data to summarize the results.

h. Define goals; from the results of the analysis can be formulated program objectives.

i. Determine what has been decided, such as the type of syllabus to be applied, the content and the teaching materials to be given, the methods or approaches to be used, and so on.

j. Evaluate procedures and results; the organizers can evaluate the series of activities that the team has done in analyzing the needs of learners to determine the program to be implemented.

Needs analysis aims to make the teaching materials which are made in accordance with the demands of competences that must be mastered by the students. The needs analysis of teaching materials includes three stages of analysis which are analysis of curriculum, learning resources, and the determination of the type and title of the teaching materials. This whole process becomes an integral part of a teachinglearning process that we cannot separate.

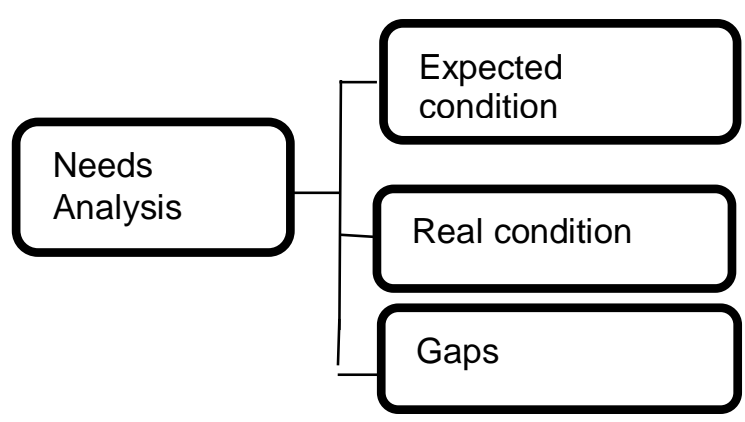

Fig. 1 Need Analysis

Hutchinson and Waters (1987) in Nation and Macalister divided needs analysis into two types of needs, namely the needs of the target and the learning needs. Hutchinson and Waters also asserted 
that the target needs analysis (targets) can be seen in the following three types.

a. The necessity is to ask: "What is required in language learning?"

b. The lacks are questioning: "What are the student shortcomings?"

c. The wish is to ask: "What do students want to learn?"

So it can be concluded by knowing the needs, shortcomings, and the desire of students in learning, teachers can accommodate these needs into the design of syllabus which can then be implemented into the pursuit stage in the classroom.

\section{METHODOLOGY}

The methodology used in this study refers to Hutchinson and Waters theory that includes the needs analysis of students and teachers. The data collecting was conducted using questionnaires in semester 5 of Chinese language and culture faculty of Darma Persada University as many as 18 students and 3 lecturers of reading class. Data analysis used quantitative approach.

\section{Table I}

Grid of Questionnaire of Needs Analysis "Model of Teaching Materials for Reading Contextual-Based Mandarin Literary Works and Culture"

\begin{tabular}{|c|c|c|c|c|c|c|}
\hline No & Aspect & Definition & Indicator & & $\begin{array}{l}\text { Total } \\
\text { item }\end{array}$ & $\mathrm{N}$ \\
\hline 1. & $\begin{array}{l}\text { Leaming } \\
\text { Objectives }\end{array}$ & $\begin{array}{l}\text { What students want to } \\
\text { achieve in leaming to } \\
\text { read Mandarin }\end{array}$ & $\begin{array}{l}\text { General } \\
\text { (reading) }\end{array}$ & purpose & 2 & $1-2$ \\
\hline
\end{tabular}

\begin{tabular}{|c|c|c|}
\hline $\begin{array}{l}\text { Specific purposes } \\
\text { (language, grammar, } \\
\text { literature and culture } \\
\text { skills) }\end{array}$ & 4 & $3-6$ \\
\hline $\begin{array}{l}\text { The theme of literature } \\
\text { and culture }\end{array}$ & 3 & $7-8$ \\
\hline Linguistics & 2 & D1-D2 \\
\hline Eading skills & 3 & $\mathrm{~A} 1-\mathrm{A} 3$ \\
\hline Literature & 1 & B4 \\
\hline Culture & 1 & B5 \\
\hline
\end{tabular}

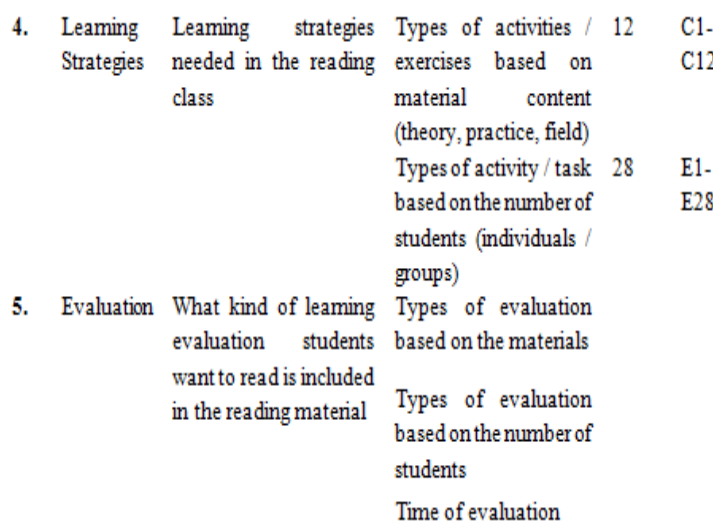

\section{RESULTS AND DISCUSSION}

Needs analysis has been done by (a) giving a questionnaire to find out the needs of the students and lecturers about teaching materials to read the Mandarin appropriately. In addition, the researchers also provide questionnaires, observations, and interviews of students and lecturers of Mandarin reading class about the problems encountered in learning to read Mandarin.

Here is a description of needs analysis that has been done with reference to the theory of Hutchinson and Waters. Needs analysis here include analysis of the needs / what the students and teachers want.

Here is the data from the needs analysis of the students in reading 5 classes obtained from nineteen students semester 5 Faculty of Literature, Department of Chinese Literature, Darma Persada University, Jakarta. The data from the answers to the question why students learn Mandarin: $60 \%$ for other reasons such as parents' demands, love Mandarin, and want to speak Mandarin, 30\% for studying in China, $10 \%$ for working in China.

The answer to the question have the students ever been studied Mandarin before: $85 \%$ had studied in high school, had studied in elementary, junior, and senior high school, $15 \%$ had never studied Mandarin before.

The data of the answers to questions do you want to master Mandarin reading skills: as many as $100 \%$ answered want to master the reading skills of Mandarin. The answers to the question whether you want to master Mandarin linguistic materials: $100 \%$ need to master the Mandarin linguistics content material. The data of the answers to the question of whether students need literary material: $92.3 \%$ need it and $7.7 \%$ do not need. The answer data to the question of whether the students of Reading 5 need the information about the culture in Indonesia: 
92.3\% stated that they need and $7.7 \%$ stated do not need.

The answer data for the question of what topic is needed by students of Reading 6: 69\% stated very need the theme of Chinese folklore, $46 \%$ desperately need the theme of Chinese legend story, $30 \%$ desperately need Chinese theme short story, $7.7 \%$ desperately need Chinese serial stories theme , $30 \%$ are in need of Chinese poetry themes, $7.7 \%$ are in need of Chinese verse themes, $7.7 \%$ are in need of Chinese drama text themes, $69 \%$ are in need of Chinese people's daily habits themes, $46 \%$ desperately need cultural site themes in China , 7.7\% desperately need Chinese profession/occupation themes. The answers to the question of what the students would most like to study in reading classes in addition to the themes mentioned earlier: $7.7 \%$ said they desperately need Chinese cultural themes and Chinese society in Indonesia, Indonesian folklore using Mandarin.

Table II

Results of Student Needs Analysis / Desire on Theme Dimension

\begin{tabular}{|l|l|l}
\hline Dimension & The Title of the Themes & Note \\
\hline Themes & Reading Chinese People's Story & Very needed \\
\hline & Reading Chinese Legend & Very needed \\
\hline & Reading Chinese Short Stories & Very needed \\
\hline & Reading Chinese serial story & Very needed \\
\hline & Reading Chinese poetry & Very needed \\
\hline & Reading Chinese verse & Very needed \\
\hline & Reading Chinese drama texts & Very needed \\
\hline & $\begin{array}{l}\text { Reading the daily habits of } \\
\text { Chinese society }\end{array}$ & Very needed \\
\hline & Reading cultural sites in China & Very needed \\
\hline
\end{tabular}

Based on the data in table 4.1 it can be concluded that the respondents stated that all the themes listed by researchers are very needed for the students of Reading 5 class. Thus these themes should be included in the Reading 5 materials. According to the students, the most needed theme is Chinese folklore.

For the data of the materials needed by the students of Reading 5 class, the researchers also identifies the needed reading material. The following are the data of needs analysis for the dimensions of language skills, language, literature, and culture.

The data of the answers to the question of reading material that you need: $53.8 \%$ of students are in need of paragraphs of the text reading material, $30.8 \%$ of students desperately need reading material of poetry, $30.8 \%$ of students very need drama text reading material, $84.6 \%$ of students really need the material on how to read the text of the story, $61.5 \%$ of students are in need of reading material of traditional Chinese food, $53.8 \%$ of students desperately need the material to read Chinese wedding ceremony, $30.8 \%$ of students really need the material on how to read Chinese funeral ceremony, $30.8 \%$ of students are in need of Chinese culture sites reading material, and $30.8 \%$ of students are in need of reading material of Chinese customs.

The data from the answers to the question about what language material needed by the students of Reading 5 class: as much as $76.9 \%$ need Chinese linguistic material 汉字, $61.5 \%$ desperately need material of alphabet Mandarin 汉语拼 音, $15.4 \%$ badly need Mandarin tone material 声调, $23 \%$ urgently need Mandarin intonation material 语调, $69.2 \%$ are in need of grammar material, and $76.9 \%$ urgently need reading comprehension material.

The answer data for the question of what literary material needed by the students of Reading 5 class: $60 \%$ of students stated that they really need prose material and only $15.4 \%$ each stated that they need poetry and drama material.

The answer data on the question of what cultural material needed by the students of Reading 6 class: $30 \%$ desperately needs material on Chinese people's ideas/values, $30 \%$ desperately need material about community activities/Chinese customs, and $40 \%$ in need of material on physical culture (traditional houses, cultural sites, and others).

The answer data for the questions of the training materials (tasks) needed by the students of Reading 5 class: $70 \%$ in need on language material and language skills, as much as $16 \%$ need literary material and $14 \%$ need cultural material.

Data answer to the question of what kind of training(task) students of Reading 5 class need: $30 \%$ of students really need practice at home, $85 \%$ of really need practice in class, $38 \%$ really need theory, and $65 \%$ really need variation of task.

Furthermore, will be presented the data of the needs for task type dimensions and evaluation. The answer data for the question of the task type based on the number of implementers needed by the students of Reading 5 class: as much as $75 \%$ are in dire need of individual tasks, $61 \%$ are in desperate need of group assignment, and $65 \%$ in need of varied tasks between individuals and groups.

The answer data for the question of the evaluation material needed by the students of Reading 5 class: $80 \%$ of the students need language material, $85 \%$ need the language skills (reading). $38 \%$ desperately need literary material, and $60 \%$ very need cultural material.

Answering the question of what type of evaluation is needed for the students of Reading 6 class: $65 \%$ need a theoretical evaluation, $80 \%$ need reading practice evaluation, $60 \%$ needs evaluation of individual tasks, and $70 \%$ need evaluation that varies between individuals and groups.

The answer data on the type of evaluation needed by the reading class students are that $69 \%$ in 
need of individualized evaluation, $61 \%$ in need of group evaluation, and $65 \%$ in dire need of evaluations that vary between individuals and groups.

The answer data on the evaluation needed by the students of Reading 5 class are $46 \%$ need the evaluation at the end of the theme lesson, $23 \%$ need an evaluation after two lesson themes, and $38 \%$ need an evaluation when all lesson theme has ended.

The following is the data table of students' needs analysis for the material dimension, task type and evaluation:

Table III

Data Analysis Needs / Desire on Dimensions of Materials, Tasks and Evaluations According to Students

\begin{tabular}{|c|c|c|c|c|}
\hline No & Materials & \multicolumn{2}{|c|}{ Indicator } & Category \\
\hline \multirow{10}{*}{$\frac{10}{1 .}$} & \multirow{10}{*}{$\begin{array}{l}\text { Leaming } \\
\text { Materials }\end{array}$} & \multirow{10}{*}{$\begin{array}{l}\text { Reading } \\
\text { Skills }\end{array}$} & Discourse Paragraph & Very needed \\
\hline & & & Poetry & Needed \\
\hline & & & Drama Texts & Needed \\
\hline & & & Story Texts & Needed \\
\hline & & & Kinds of Foods & Needed \\
\hline & & & Discourse Paragraph & Needed \\
\hline & & & Wedding Ceremony & Needed \\
\hline & & & Funeral Ceremony & Needed \\
\hline & & & Kinds of Cultural Sites & Needed \\
\hline & & & Chinese Customs & Needed \\
\hline
\end{tabular}

\begin{tabular}{|c|c|c|c|c|}
\hline No & Materials & Indicator & & Category \\
\hline \multirow[t]{6}{*}{2.} & \multirow{6}{*}{$\begin{array}{l}\text { Leaming } \\
\text { Matenials }\end{array}$} & \multirow[t]{6}{*}{ Lingustics } & Mandarin Script（汉字) & \begin{tabular}{|l} 
Very needed \\
\end{tabular} \\
\hline & & & Mandarin Alphabets (汉语弹音) & Needed \\
\hline & & & Mandarin tones（声谓） & Needed \\
\hline & & & Mandarin intonations (语调) & Needed \\
\hline & & & Grammars & Needed \\
\hline & & & Reading Comprehension & \begin{tabular}{|l} 
Very needed \\
\end{tabular} \\
\hline
\end{tabular}

\begin{tabular}{|c|c|c|c|c|}
\hline No & Materials & \multicolumn{2}{|c|}{ Indicator } & Category \\
\hline \multirow{3}{*}{3.} & \multirow{3}{*}{$\begin{array}{l}\text { Leaming } \\
\text { Materials }\end{array}$} & \multirow{3}{*}{ Sastra } & Drama & Less needed \\
\hline & & & Poetry & Needed \\
\hline & & & Prose & Very needed \\
\hline
\end{tabular}

\begin{tabular}{|l|l|l|l|l|}
\hline NO & Materials & \multicolumn{2}{|l|}{ Indicator } & Category \\
\hline 4. & $\begin{array}{l}\text { Leaming } \\
\text { Matenals }\end{array}$ & Culture & $\begin{array}{l}\text { Idea/value of life; Chinese } \\
\text { manners }\end{array}$ & Needed \\
\cline { 3 - 5 } & & $\begin{array}{l}\text { Community activities/ community } \\
\text { habits }\end{array}$ & Needed \\
\cline { 3 - 5 } & & $\begin{array}{l}\text { Physical culture, traditional house } \\
\text { and others }\end{array}$ & Needed \\
\hline
\end{tabular}

Based on the table above, it can be concluded that for the language skills material students stated that the material that is needed in reading class is reading paragraphs of discourse. For linguistic material they really need Chinese characters (汉字) and reading comprehension. For literature materials they are in need of prose. For cultural material, all of cultural material indicators are needed by students.

On the exercise dimension students feel very need of language skills practice. Students also expect tasks are given variably between individual and group tasks.

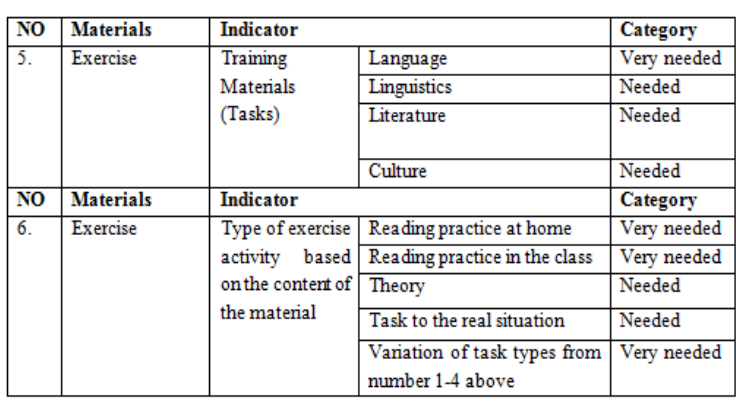

\begin{tabular}{|c|c|c|c|c|}
\hline \multirow{4}{*}{$\begin{array}{l}\text { NO } \\
7 .\end{array}$} & Materials & \multicolumn{2}{|l|}{ Indicator } & Category \\
\hline & \multirow{3}{*}{ Exercise } & \multirow{3}{*}{$\begin{array}{l}\text { Types of exercise } \\
\text { activity based on } \\
\text { the number of } \\
\text { students }\end{array}$} & Individual & Needed \\
\hline & & & Group & Needed \\
\hline & & & $\begin{array}{l}\text { Variations between } \\
\text { individuals and groups }\end{array}$ & Needed \\
\hline
\end{tabular}

\begin{tabular}{|l|l|l|l|l|}
\hline NO & Materials & Indicator & Category \\
\hline 8. & Evaluation & Evaluation & Language & Very needed \\
\cline { 4 - 5 } & & \multirow{2}{*}{ Materials } & Linguistics & Needed \\
\cline { 4 - 5 } & & & Literature & Needed \\
\cline { 3 - 4 } & & & Culture & Needed \\
\hline
\end{tabular}

\begin{tabular}{|c|c|c|c|c|}
\hline No & Materials & \multicolumn{2}{|l|}{ Indicator } & Category \\
\hline \multirow[t]{5}{*}{9.} & \multirow{5}{*}{ Evaluation } & \multirow{5}{*}{$\begin{array}{l}\text { Type of } \\
\text { evaluation } \\
\text { based on the } \\
\text { content of } \\
\text { the material }\end{array}$} & Reading practice at home & Very needed \\
\hline & & & Reading practice in the class & Very needed \\
\hline & & & Theory & Needed \\
\hline & & & Task to the real situation & Needed \\
\hline & & & $\begin{array}{l}\text { Variation of task types from } \\
\text { number } 1-4 \text { above }\end{array}$ & Very needed \\
\hline
\end{tabular}

\begin{tabular}{|c|c|c|c|c|}
\hline No & Materials & \multicolumn{2}{|l|}{ Indicator } & Category \\
\hline \multirow[t]{3}{*}{10.} & \multirow[t]{3}{*}{ Evaluation } & \multirow{3}{*}{$\begin{array}{l}\text { Type of evaluation } \\
\text { based on the } \\
\text { number of students }\end{array}$} & Individual & Needed \\
\hline & & & Group & Needed \\
\hline & & & $\begin{array}{l}\text { Variations between } \\
\text { individuals and groups }\end{array}$ & Needed \\
\hline
\end{tabular}

\begin{tabular}{|l|l|l|l|l|}
\hline NO & Materials & \multicolumn{2}{|l|}{ Indicator } & Category \\
\hline 11. & Evaluation & Time of evaluation & $\begin{array}{l}\text { Evaluate at the end of the } \\
\text { unit lesson }\end{array}$ & Needed \\
\cline { 4 - 5 } & & $\begin{array}{l}\text { Evaluation after two or } \\
\text { more unit lessons }\end{array}$ & Needed \\
\cline { 3 - 5 } & & $\begin{array}{l}\text { Evaluation after all unit } \\
\text { lessons }\end{array}$ & Needed \\
\hline
\end{tabular}

The evaluation dimension, the students need an evaluation of language proficiency and language competence. A much needed type of evaluation is the varied evaluation of theory and practice in the classroom. Students prefer individual evaluation and are implemented after a unit of material has been studied.

\section{Needs Analysis of the Lecturers of Reading 5 Class of Mandarin}

These are the results of the questionnaire of needs analysis given to the three lecturers of faculty of Chinese Literature. The results of the evaluation 
are then clarified by the interviews. The lecturers have Chinese linguistic backgrounds with qualifications of two S3 graduates and one S2 graduate. The lecturers have experienced of teaching the Mandarin language for 5-15 years, they have experienced of teaching reading Mandarin.

The data from the answers to the question which language mastery do you think is most important for the Mandarin reading class?, 60\% answered the importance of Chinese letters (汉字), $20 \%$ answered the importance of tone (声调) and $20 \%$ answered the importance of mastery of sentence / words.

Next basic question is do you use to set the learning goal of reading Mandarin?, 35\% stated based on the results of discussions with other groups of teachers, $35 \%$ stated based on interviews with educational institutions (managers of educational programs) where you teach and $30 \%$ based on results research needs analysis.

Questions about You think, on what aspects of orientation the learning end goal of reading Mandarin - as many as $60 \%$ answer reading content knowledge and $40 \%$ answer reading skills.

Other question Do you think what efforts need to be done to improve the effectiveness of learning to read Mandarin?, as many as $60 \%$ answer the importance of designing learning programs based on the results of the needs analysis of students and $40 \%$ answered the importance of designing a special syllabus of learning to read Mandarin.

The sixth question is what steps need to be taken to improve the effectiveness of Mandarin teaching learning, as much as $20 \%$ answered designing various learning strategies, $20 \%$ stated the need to use interesting learning media, $20 \%$ stated the need to design student-centered learning activities, $20 \%$ stated the appropriate teaching materials need to be developed and $20 \%$ stated the need to be designed an interesting and appropriate exercise for the students.

Questions on how to make the right teaching materials to be used in learning to read Mandarin, all respondents answered $100 \%$ need of textbooks equipped with exercises and elements of learning support.

For questions How to present what teaching materials do you use most in learning to read Mandarin? as many as $40 \%$ answered the need for discussion, $30 \%$ answered the need for assignment and $30 \%$ answered the need to practice reading together/individual. The next question What are the difficulties faced by the students in following the Mandarin lessons you are developing? $40 \%$ of respondents answered the difficulty of obtaining adequate teaching materials, 30\% answered the difficulty Students complete the exercises and $30 \%$ answered the difficulty Students get enough guidance.

The final question on evaluation How do you evaluate learning to read Mandarin, as many as $30 \%$ perform formative evaluation in the form of subjective tests, $30 \%$ conduct evaluation through Student work (exercise/assignment) and $40 \%$ conduct summative evaluation (final semester) in subjective test form.

Based on the explanation above, it can be concluded the importance of Hanzi mastery in the reading class and the ability to analyze reading results by the students. For the making of learning tools such as syllabus required discussion with colleagues and the managers of education and needs analysis. Evaluation conducted in the reading class is summative evaluation, task individually and in groups.

\section{CONCLUSION AND SUGGESTION}

As mentioned before, the needs analysis in this study used the theory of Hutchinson and Waters. Needs analysis here include the analysis of needs, shortcomings and desires. Analysis includes the needs analysis conducted on students and lecturers of reading class.

Based on the result of needs analysis (recapitulation table of the needs are attached) it can be stated that the purpose of the students to learn Mandarin varies, ranging from the demands of parents, like Mandarin and want to speak Mandarin, because they will continue study and work in China. Students $(100 \%)$ said they wanted to master Mandarin reading skills. Furthermore, linguistic competence $(100 \%)$ states that it requires mastery of Mandarin language material, cultural material $(92.3 \%)$ and literary material $(92.3 \%)$.

In relation to the foundation of the development of teaching materials, it states (100\%) the need for reading textbooks equipped with exercises and learning support elements and in accordance with the needs of the students, universities, and linguistic users later. Also look at contextual-based teaching guidelines.

For literary themes, students $(69 \%)$ claimed that need Chinese folklore themes and Chinese legend stories (46\%). The cultural theme of the students $(69 \%)$ states that they need Chinese people's daily habits theme, and the theme of Chinese cultural sites $(46 \%)$.

For literature reading materials, the students and lecturers alike to declare experiencing obstacles in classic Mandarin language contained in the text. The reading material that needed should use modern Mandarin language that is easy to read and understood by students and teachers. It is aligned with the competence of Mandarin which has been studied. 
For linguistic material, $76.9 \%$ of students stated that they need Chinese linguistic material 汉 字, 61,5\% need Chinese alphabet material 汉语拼. Students $(69.2 \%)$ need grammar material and $76.9 \%$ need reading comprehension material.

For the form of reading material of literature and culture used by the students, they $(53,8 \%)$ need reading material of discourse paragraph, student $(84,6 \%)$ need material reading story text. So it is concluded that narrative text is used in every reading theme.

For training materials and evaluation based on needs analysis it can be concluded that $70 \%$ need practical materials of linguistic materials, and language skills, as much as $16 \%$ desperately need literary materials and $14 \%$ desperately need cultural material. So the type of exercise used by $85 \%$ of students claimed to require classroom practice, and $65 \%$ of students claimed to need a variety of tasks. Regarding the exercise will be adapted to the contextual learning guide discussed in chapter II. The exercise is used to improve students' reading competency.

In terms of technical workmanship of most students feel the task of groups and individuals there is no difference of difficulty but should be done and studied in class. For the evaluation material, this type of evaluation will be more emphasized by reading comprehension as it is adapted to the contextual learning that has been presented in chapter II.

For the type of student materials $65 \%$ need a theory-based evaluation, $80 \%$ need an evaluation of reading practice, $60 \%$ need an individual task evaluation and $70 \%$ require evaluation that varies between individuals and groups.

For $69 \%$ student test techniques requiring individual evaluation, $61 \%$ require group evaluation and $65 \%$ require varying evaluations between individuals and groups.

For the time of the test $46 \%$ of the students stated that evaluation is needed at the end of the lesson theme, $23 \%$ of students stated that evaluation is needed after two lesson themes, and $38 \%$ of students stated that evaluation is needed when all lesson themes are over.

\section{ACKNOWLEDGMENT}

We would like to thank Causal Productions for permits to use and revise the template provided by Causal Productions. Original version of this template was provided by courtesy of Causal Productions (www.causalproductions.com).

\section{REFERENCES}

Brown, James Dean. 1995. The elements of Language Curiculum : A Systematic Approach to Program Development. Boston: Heinle\&Heinle Publisher.

C, Jack Richards. 2001.Curriculum Development in Language Teaching. Cambridge.

C, Jack Richards and T.S. Rodgers. 2001. Approaches and Methods in Language Teaching:A Description and Analysis. Cambridge.

Dai L, Zhang C, Liu X. A special Chinese reading acceleration training paradigm: To enhance the reading fluency and comprehension of Chinese children with reading disabilities. Frontiers in Psychology Journals, December 12, 2016. DOI: 10.3389/fpsyg.2016.01937.

Emzir. 2012. Metodologi Penelitian Pendidikan: Kuantitatif \& Kualitatif (Edisi Revisi). Jakarta: Rajawali Press.

Jiang, Xiangying, Sawaki, Yasuyo,Sabatini, John. Word reading efficiency, text reading fluency, and reading comprehension among Chinese learners of English. Reading Psychology Journals, 2012.DOI : :10.1080/02702711.2010.526051, ISBN :0270-2711.

Macalister, John. 2010.Language Curriculum Design. London: I.S.P Nation.

Munby,J. 1978. Communicative Syllabus Design. Cambridge :Cambridge University Press.

R.R, Jordan. 2003.English for Academic Purposes, A Guide and Resources Book for Teachers.Cambridge: Cambridge University Press.

The office of Chinese language council international. 2008. Chinese language proficiency scales for speakers of other language. Beijing: Foreign language teaching an research press.

The Office of Chinese Language Council International. 2008. International Curicculum for Chinese Language Education. Beijing: Foreign Language Teaching and Research Press.

The Office of Chinese language council International. 2008. Standards for teachers of Chinese to speakers of other language. Beijing: Foreign Language teaching and research press. 